\title{
Leiomyosarcoma and Endometrial Stromal Sarcoma Pathologic Distant Metastasis TNM Finding v7
}

National Cancer Institute

\section{Source}

National Cancer Institute. Leiomyosarcoma and Endometrial Stromal Sarcoma

Pathologic Distant Metastasis TNM Finding v7. NCI Thesaurus. Code C89600.

A pathologic finding about one or more characteristics of leiomyosarcoma and endometrial stromal sarcoma, following the rules of the TNM AJCC V7 classification system as they pertain to distant metastases. There is no pathologic M0. (from AJCC 7th Ed.) 